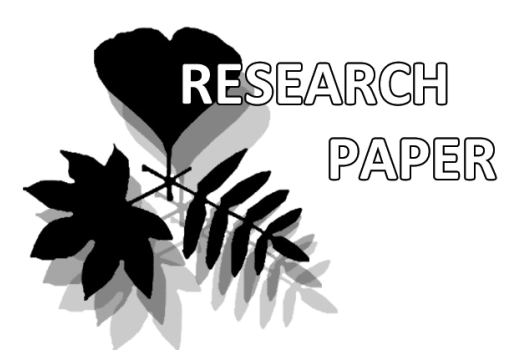

Vadim A. Bakalin *

e-mail: vabakalin@gmail.com

Elena V. Butorina

e-mail:07elena07@bk.ru

Ksenia G. Klimova

e-mail: ksenia.g.klimova@mail.ru

Botanical Garden-Institute FEB RAS, Vladivostok, Russia

* corresponding author

Manuscript received: 20.10.2016

Review completed: 18.07.2017

Accepted for publication: 30.07.2017

Published online: 31.07.2017

\section{The Hepaticae and Anthocerotae of Kedrovaya Pad' Nature Reserve - an intact enclave of East Manchurian flora in Russia}

\author{
Vadim A. Bakalin*, Elena V. Butorina \& Ksenia G. Klimova
}

\begin{abstract}
A B S T R A C T
The updated checklist of Hepaticae and Anthocerotae for Kedrovaya Pad' Nature Reserve is compiled based on literature sources and own studies. The checklist counts 74 species (and 2 varieties), with 35 species newly recorded for the reserve. Calypogeia tosana is recorded for the first time for Russia. The flora of the reserve is rather typical for cool temperate zone of East Manchuria and houses several taxa known in Russia from studied nature reserve only.

Ke yw or d s : Hepaticae, Anthocerotae, East Manchuria, the Russian Far East, Kedrovaya Pad' Nature Reserve, conservation, Calypogeia tosana
\end{abstract}

\section{P Е 3 Ю M E}

Бакалин В.А., Буторина Е.В., Климова К.Г. Печеночники и антоцеротовые заповедника «КеАровая Падь» - нетронутого анкиава восточноманьчжурской фморы в России. На основе опубликованных ранее материалов и результатов полевых работ авторов состав ен новый список печеночников и антоцеротовых заповедника «Кедровая Падь», включающий 74 вила (в том числе 2 разновиАности), из которых 35 виАов Аля рассматриваемой территории указывается впервые. Calypogeia tosana приводится впервые Аля России. ФАора заповедника достаточно типична Аля прохлаАной умеренной зоны Восточной Маньчжурии и содержит несколько таксонов, известных в России только с изученной территории.

Км оче вы е скова: Hepaticae, Anthocerotae, Восточная Маньчжурия, российский Аальний Восток, заповедник «КеАровая Падь», Calypogeia tosana
Kedrovaya Pad' State Nature Reserve, one of the oldest and the southernmost reserves in Russia, is situated near Amur Bay of the Sea of Japan on the spoors of EastManchurian Mountains. If looking from the space, the southernmost fringe of the Russian Far East (Primorsky Territory) has three main meridionally oriented landscape entities: 1) densely forested North-Eastern spoors of East Manchurian mountains that connected by continuous series of middle-elevation mountains with the highest point of Manchuria - Changbai Mt. (2700 m alt., straight line length from the central point of the reserve to the peak of the latter is $310 \mathrm{~km}), 2$ ) forestless steppes somewhat similar to prairies, floodplain meadows, scattered Quercus woodlands and flat agricultural lands around Khanka Lake and stretching southward along the both sides of Razdol'naya River and southward along sea coast to Tumangan River in the Russian-North Korean (DPRK) administrative border, 3) densely forested Sikhote-Alin Range and its numerous spoors (that represent middle-elevation subordinate ranges). The basic idea of our study was the assumption that some Korean-Japanese taxa in the course of the dissemination northward might access north-easternmost fringe of East-Manchurian Mountains, but could not 'pass' Khanka Lowland and therefore could not to be occurred in SikhoteAlin Range.

The latter reason inspired the first author to organize the field study of liverwort flora of the Reserve despite the last checklist of hepatics of the reserve based on several years work by S.K. Gambaryan was published as recently as in 2002 (Gambaryan \& Cherdantseva 2002). The latter includes 149 moss species and 30 species of hepatics - the number estimated as rather far from the reality. Several taxa were added in the recent years by other authors: Asterella cruciata was added by Borovichev et al. (2015), Bazzania denudata and B. parabidentula - by Bakalin (2016), Clevea nana - by Borovichev \& Bakalin (2013), Conocepalum salebrosum - by Borovichev et al. (2009), Cylindrocolea kiaerii - by Bakalin and Mamontov in Ellis et al. (2016), Porella spinulosa - by Potemkin (2008) and Riccia bifurca and R. beyrichiana - by Borovichev \& Bakalin (2016a).

\section{Study area}

The high value of the land that currently known as "Kedrovaya Pad' was understood as far as in the beginning of 20th century that resulted in organization of the reserve in 1916 (Vasilyev et al. 1965). After 1916, when the area of the reserve was about 4500 ha, it was enlarged in 1926 to 9500 ha and to 17500 ha in 1951 that after clarification of the area basing on new satellite facilities was clarified as covering over $18000 \mathrm{ha}$ (= $180 \mathrm{sq} . \mathrm{km}$ ) (Vasilyev et al. 1984, Azbukina et al. 2002). The shape of Kedrovaya Pad' is similar to square, the eastern margin of which is situated ca. $3 \mathrm{~km}$ inland of Amur Bay of Sea of Japan. The 'square' covers the valley of Kedrovaya (= the Korean pine) River 


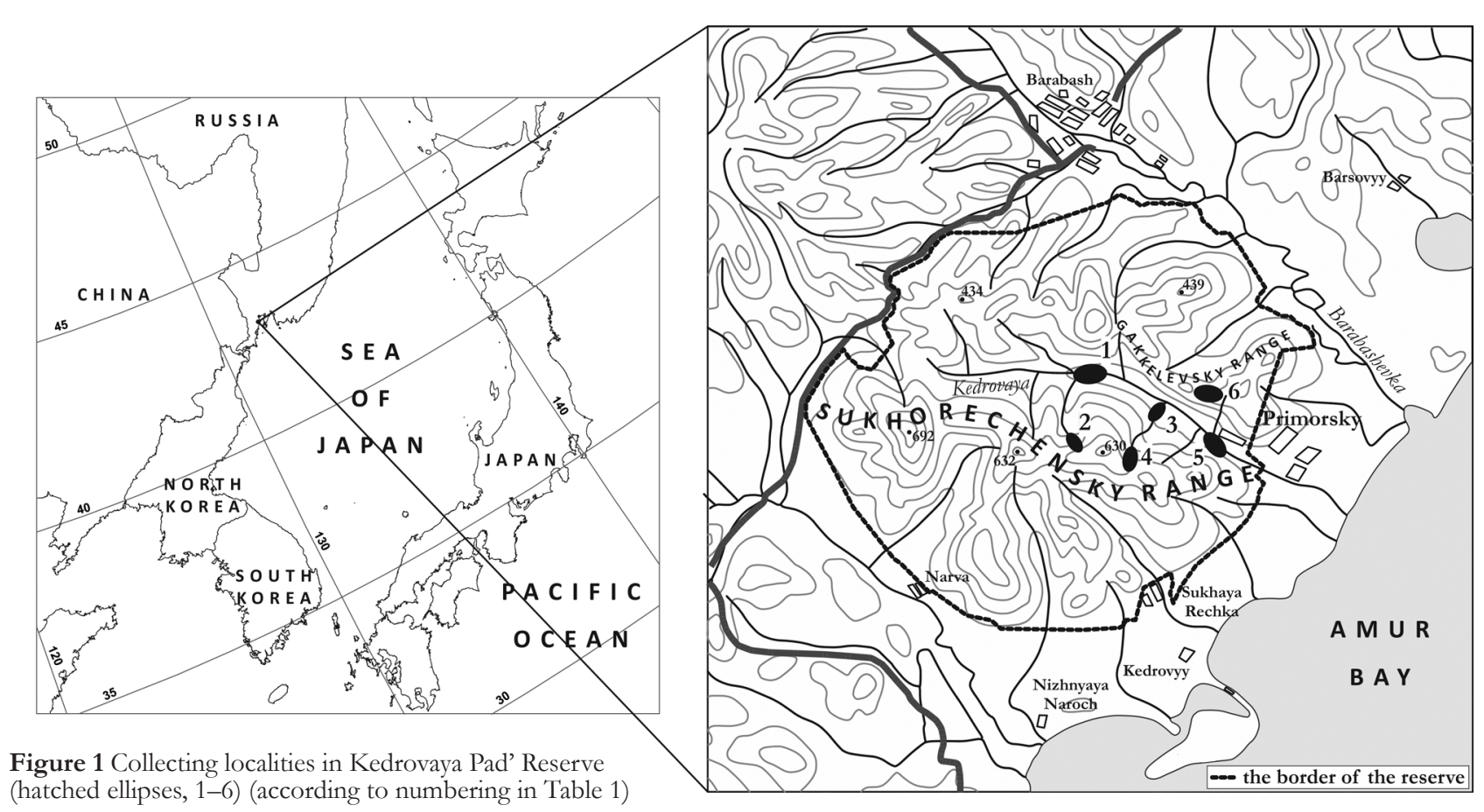

Basin and mountain ranges on the both sides of the valley (Sukhorechensky and Gakkelevsky Ranges, Fig. 1), which are connected in uppermost part of the River. Latitudinally it stretches for ca $20 \mathrm{~km}$ at the latitude near $43^{\circ} \mathrm{N}$. The dominant elevation is between 50 and $400 \mathrm{~m}$ a.s.l., with the highest point little below $700 \mathrm{~m}$ a.s.l.

Climate of the reserve has typical monsoon character: wet warm summer and dry cold winter, although it is relatively milder in winter then just inland of it due to proximity to the sea that is not freezing in winter (Rakova 1992). Annual mean temperature is about $+4^{\circ} \mathrm{C}$ (January mean temperature ranges from -13 to $-15^{\circ} \mathrm{C}$, August - from +20 to $+22^{\circ} \mathrm{C}$ ); annual precipitation varies around $900 \mathrm{~mm}$ per year (Azbukina et al. 2002). Geomorphological elements of the land formed on strata of Mesozoic origin and composed by sandstones and argillaceous and sandy slates (Vasilyev et al. 1984). Due to loose compressing of the rocks and high diversity in elevation, the drainage abilities of the landscapes are relatively high (Vasiljev et al. 1984).

The flora of the Reserve is prominent among hilly landscapes of south-east part of Primorsky Territory due to large distribution and abundance of two dark-coniferous trees: Abies holophylla Maxim (not passing southward of the southern spoors of Sikhote-Alin Range) and Pinus koraiensis Siebold et Zucc. (the taxon of broadly Manchurian distribution) in association with many broadleaved deciduous trees like Kalopanax, Acer, Phellodendron, etc. Beyond Kedrovaya Pad', within southwestern part of Primorsky Territory, these trees are uncommon and never form continuous communities. Forested landscapes are mostly covered by impoverished Quercus dentata Thunb. forests of unclear origin (probably formed under impact of human activity, cf. Nakamura \& Krestov 2005).

The slopes of the ranges in Kedrovaya Pad' Reserve are covered by peculiar forest called as Manchurian taiga that is natural and highly stable mixture of Abies, Pinus and many broadleaved trees. Near valley beds these forests gradually transform into broadleaved forests (although solitary pine and fir trees may remain even in lowland). The dominant vegetation in the Kedrovaya River flood plain are forests formed by Salix (Salix gracilistyla Miq., S. schwerinii E.L. Wolf., S. sinzewii Seemen), Chosenia arbutifolia (Pall.) A. Skvorts., Alnus hirsuta Turcz., A. japonica Siebold. et Zucc. and Fraxinus mandshurica Rupr., etc. On the north-facing slopes in higher elevation (300-500 m a.s.l.) typical Manchurian forest contrary pass into pure dark coniferous communities. The ridge line covered by mostly closed Quercus mongolica forest with many (dry of rarely mesic) outliers or solitary large blocks with Rhododendron mucronulatum Turcz. s.l. dense thickets. Only a few outliers are open to sun.

Vascular plant flora is the best studied group among plants and fungi in the reserve. Despite small size of the reserve, its flora shows high diversity that consists of one fourth of total species diversity of vascular plants in the Russian Far East. The following examples are illustrative: the reserve houses all (8 species) of Acer known in Primorsky Territory, 5 of 6 species of Betula, two endemics with narrow area (Allium prokhanovii (Worosch.) Barkalov and Neottia ussuriensis (Kom. \& Nevski) Soó), etc. The most of specificity is certainly concentrated within group of Manchurian or (in more broad aspect) East Asian distribution.

Kedrovaya Pad' is one of the best-studied nature reserves in the Russian Far East that may be explained by relatively small size, proximity to Vladivostok (the city with large academic infrastructure) and easy access of any part of the area. As the result of long and purposeful researchers the list of vascular plants of Kedrovaya Pad counts 913, fresh water algae - 273, fungi - 1804 and lichens - 250 species (Azbukina et al. 2002). 


\section{MATERIAL AND METHODS}

The senior author has visited Kedrovaya Pad' two times with short field surveys: 5 days in May 2007 and then 4 days in 2015. In total ca. 350 specimens were collected. The collection of 2015 was identified immediately after gathering when plants remained alive to study oil bodies characteristic. The vouchers are in VBGI. The main collection locals (Table 1) although not distributed evenly across the reserve (Fig. 1), but covers virtually all existing vegetation types in the latter.

\section{RESULTS AND DISCUSSION}

The basic expression after the work in the reserve is that the land is too dry for the majority of hepatics. Indeed, the most taxonomically diverse belt (for bryophytes) in the southern flank of the Russian Far East is the diapason between 600 and $1000 \mathrm{~m}$ a.s.l. that intercepts larger amount of air moisture going from the Pacific, but yet is not too cool (Bakalin 2008).

However, even in present, not very favorable, conditions 74 species and two varieties are now documented by present work and earlier list by Gambaryan \& Cherdantseva (2002). Thirty five species are new for the reserve, 21 species were reconfirmed after Gambaryan \& Cherdantseva (2002) and 10 species we were unable to find in the land. Some of them may be omissions in our study (Conocephalum japonicum, Marchantia polymorpha, Pellia neesiana, Phaeoceros laevis) that may be found if more precise attention would be paid to waste land where these taxa likely to be occurred in the nature reserve. Plagiochila hakkodensis is the species of more southern distribution and is the rarity that is easy to mistake in the field with P. ovalifolia and therefore did not collect. Local occurrence of Porella gracillima is possible in lower altitude on Ca-rich substrata those were not meet in our study.

Nevertheless, the report of some taxa by Gambaryan \& Cherdantseva (2002) may be based on misidentifications. Such, Mylia taylorii could be hardly expected in such altitude and the report is probably based on poorly developed M. verrucosa. The same may be applied to Plectocolea ovalifolia, recorded in Gambaryan \& Cherdantseva (2002) as P. infusca var. ovalifolia. The latter species may occur in our latitude only in much higher elevation. The record of Radula complanata (the 'rarity' of higher elevations in southern part of Primorsky Territory) may represent misidentification for R. constricta. Unfortunately we were not able to locate the specimen on which this record is based in VLA.

Twenty one species those were recorded in Gambaryan \& Cherdantseva (2002) and were reconfirmed belong to the group of taxa that widely distributed in cool temperate zone of eastern Asia (or broadly Manchurian) and might be easily expected in the reserve. The most of our new records for the reserve belong to the latter group as well. However, among taxa we found some species that may provide some phytogeographical interest.

Korean-Japanese Calypogeia tosana belongs to the group of taxa were not known in Russia yet. This is one of confirmation of our expectation that inspired our researches in the land. Indeed this species is passing through Korean Peninsula but does not reach Sikhote-Alin. The similar pattern is shown Odontoschisma pseudogrosseverrucosum, the recently described taxon (Aranda et al. 2014) that replaces northward of subtropics morphologically closed (but distanced in the terms of genetic) O. grosseverrucosum Steph. The former has also Japanese-Korean distribution and reaches Russia only in Kedrovaya Pad'. The similar pattern (although more broad distribution in East Asia) shows Scapania ciliata known in Russia in Kedrovaya Pad' only.

Another phytogeographical important record is Cylindrocolea kiaeri - basically Paleotropic suboceanic taxon, for which this record is northernmost in the world. The fourth noticeable record is the location of Lepidozia subtransversa, the species fairly common in northern Japan and locally abundant in South Korean mountains. Before it was recorded for the first time for Russia (Choi \& Bakalin 2012) from the southern spoors of Sikhote-Alin. However, later we were inclined to treat this species as extinct in the Russian flora because of mudflow that totally destroyed the habitat of this species in the known location and failure of our attempts to find it in nearby streams. The present record is also interesting by the fact this species was found in unusually low altitude, but in the area belonging to so-called wind-hole surroundings.

The latter phenomenon is more or less exhaustively studied in Korean Peninsula in the view of vascular plants (Kong et al. 2011, 2012), but not for bryophytes. The basic principle of the latter phenomenon is in the following: the wind enters to large holes in several dozens of meters above and then goes underground among more or less wet stones and cliffs (in complete darkness) and strongly decrease the temperature due to processes of water transpiration from the stones. As the result, at the exit of wind hole, the air temperature may be for around 10 degrees lower than in nearby environs. These 'air exit' areas are the place for occurrence of some higher altitude species in unusually low elevations. This interesting phenomenon was before described for Mannia triandra (Scop.) Grolle in South Korea (Borovichev \& Bakalin 2016b).

Table 1. Collecting localities in Kedrovaya Pad' Reserve

\begin{tabular}{lllcc}
\hline & Coordinates & Description & Altitude, m asl & Date of collecting \\
\hline 1 & $43^{\circ} 07^{\prime} \mathrm{N}, 131^{\circ} 28-29^{\prime} \mathrm{E}$ & Kedrovaya River Valley in its middle course & $130-140$ & 16 May 2007, 10 July 2015 \\
2 & $43^{\circ} 05^{\prime} \mathrm{N}, 131^{\circ} 30^{\prime} \mathrm{E}$ & Upper course of the Vtoroj Zolotoj Stream & 500 & $18 \mathrm{May} 2007$ \\
3 & $43^{\circ} 05^{-06} \mathrm{~N}, 131^{\circ} 31^{\prime} \mathrm{E}$ & Lower course of the Pervyj Zolotoj Stream & $286-330$ & $17 \mathrm{May} 2007,11 \mathrm{July} 2015$ \\
4 & $43^{\circ} 05-06^{\prime} \mathrm{N}, 131^{\circ} 32^{\prime} \mathrm{E}$ & Upper course of the Pervyj Zolotoj Stream & $150-320$ & $9,11 \mathrm{July} 2015$ \\
5 & $43^{\circ} 06^{\prime} \mathrm{N}, 131^{\circ} 32-33^{\prime} \mathrm{E}$ & Kedrovaya River Valley in its lower course & $\sim 60$ & $8,10 \mathrm{July} 2015$ \\
6 & $43^{\circ} 06^{\prime} \mathrm{N}, 131^{\circ} 34^{\prime} \mathrm{E}$ & Kedrovaya River left terrace in lower course of the river & 50 & 19 May 2007 \\
\hline
\end{tabular}


The number of recorded species is relatively high for hilly landscape of cool temperate East Asia under monsoon climate. This suspects that the knowledge level of the liverwort and hornwort flora is relatively close to exhaustive, although new records are certainly possible. Despite special searches we did not find such species as Microlejeunea ulicina (Taylor) Steph., Scapania ampliata Steph., Nipponolejeunea subalpina (Horik.) S. Hatt and several other taxa that may occur in the reserve. If the special researches will be organized again, the search of such taxa of Korean-Japanese or more broadly Sino-Japanese taxa should be continued.

The search of some Korean-Japanese taxa that might access north-easternmost fringe of East-Manchurian Mountains, but could not 'pass' Khanka Lowland and therefore could not to be occurred in Sikhote-Alin Range has revealed in a few taxa known in Russia from that area whereas do not known in the rest of Russia. Three bright examples are the occurrence of widely pantropical Cylindrocolea kiaerii and East Asian Odontoschisma pseudogrosseverrucosum and Scapania ciliata. Two other East-Asian taxa: Porella spinulosa (recorded by Potemkin 2008) and Calypogeia tosana may be conditionally referred to this group too, although for the species rank of the first taxon we are in doubt and the latter may be likely found in other part of the South of the Russian Far East (e.g. in South Kurils).

In general view the Kedrovaya Pad' Nature Reserve is intact enclave of East Manchurian flora that has no analogues in the Russian Manchuria. The aforementioned phytogeographically important records are the only the part of the bulk of liverwort taxa whose distribution limited in Russian part of East Manchurian mountains by the reserve. The rest land is covered in its large extension by grasslands, scattered to dense Quercus forests with only a few locally distributed small massifs of Abies and Pinus communities and are very poor in the hepatics. The latter confirm the high status of Kedrovaya Pad' Nature Reserve in the conservation of this the only virtually intact fragment of virgin mesophilic forests in Southeast of Primorsky Territory also in the view of liverwort taxonomic diversity. The latter is therefore the same as it was before known for other groups of the biota (Azbukina et al. 2002).

\section{List of taxa}

Below we provide the list of liverworts and hornworts of Kedrovaya Pad' Nature Reserve, including previously recorded taxa, with the following annotations divided by semicolons: locality number (starting from the upper case letter L), altitude range in the reserve, ecology, accompanying taxa (if any), specimen numbers, literature reference for previous record (if any). For taxa not found in our collection, the literature reference is provided. The taxa are arranged alphabetically. The nomenclature generally follows Söderström et al. (2016), with the following alterations: the treatment of Clevea nana is in accordance with Borovichev \& Bakalin (2013) and Plectocolea is treated as the genus separate from Solenostoma following to Bakalin et al. (2014). The newly recorded taxa are marked with asterisk.
Acrolejeunea sandvicensis (Gottsche) Steph. (=Trocholejeunea sandvicensis (Gott.) Mizut.) (Gambaryan \& Cherdantseva 2002).

*Aneura pinguis (L.) Dumort. - L3, 4; 500; decaying wood in part shade in mixed forests; in pure mats or together with Liochlaena subulata, Lophocolea heterophylla; P-3-3407, P 40-6-15.

Asterella leptophylla (Mont.) Grolle. - L3, 4, 5; 60-320; mesic to moist cliffs along streams in part shade, in mixed and broadleaved forests; in pure mats; P-2-12-07, P-37-1915, P-40-21-15, P-37-20-15, P-38-5-15, P-38-7-15. Also recorded in Gambaryan \& Cherdantseva (2002).

Asterella cruciata (Steph.) Horik. - Borovichev et al., 2015.

*Bazzania denudata (Lindenb. et Gottsche) Trevis. L2, 3, 4; 150-500; decaying wood and trunk base in mixed and broadleaved forests; in pure mats or together with $S_{y z y}$ giella autumnalis, Lepidozia reptans, Odontoschisma pseudogrossiverrucosum, Reboulia hemisphaerica, Scapania ciliata, Tritomaria exsecta; P-2-17-07, P-2-29-07, P-2-39-07, P-2-47-07, P-3-207, P-3-3-07, P-3-25-07, P-3-36-07, P-3-37-07, P-3-46-07, P-37-21-15, P-40-11-15, P-40-12-15, P-37-6-15.

*Bazzania parabidentula Bakalin - L2; 500; decaying wood in mixed forest; together with Metacalypogeia cordifolia, Scapania ciliata; P-3-27-07. The specimen was cited in Bakalin (2016).

*Blepharostoma minor Horik. - L4; 150; mesic cliffs in part shade in mixed forests; in pure mats; P-37-7-15.

*Blepharostoma trichophyllum (L.) Dumort. var. trichophyllum - L3, 4; 320-330; mesic boulders and cliffs in part shade, in mixed forests; in pure mats; P-41-16-15.

*Calycularia laxa Lindb. \& Arnell. - L3, 4; 150-286; mesic cliff crevices in part shade, in mixed forests; in pure mats or together with Metacalypogeia cordifolia, Plagiochila ovalifolia; P-2-14-07, P-2-11-07, P-37-5-15.

*Calypogeia azurea Stotler \& Crotz. - L1, 2, 3; 140-500; moist decaying wood in mixed and coniferous forests; in pure mats or together with Fuscocephaloziopsis lunulifolia, Liochlaena subulata; P-3-30-07, P-3-33-07, P-39-3-15, P-41-8-15, P-41-10-15, P-39-4-15, P-39-4-15.

*Calypogeia tosana (Steph.) Steph. - L4; 320; moist cliff in part shade in mixed forest; in pure mats; P-40-24-15.

*Cephalozia cf. lacinulata (J.B. Jack ex Gottsche et Rabenh.) Spruce - L4; 320; moist decaying wood in part shade in mixed forest; in pure mats; P-40-7-15, P-40-4-15.

*Cephalozia otaruensis Steph. - L2, 3, 4, 5; 60, 150-500; decaying wood and moist boulders in mixed and broadleaved forests; in pure mats or together with Riccardia palmata, Scapania parvitexta, Tritomaria exsecta; P-3-38-07, P-415-15, P-36-5-15, P-36-4-15, P-37-1-15, P-41-6-15.

*Cephaloziella spinicaulis Douin. - L1; 130; mesic cliffs, in part shade in broadleaved forest; in pure mats; P-1-24-07.

Chiloscyphus pallescens (Ehrh.) Dumort. - L3; 286; wet stones along stream in mixed forest; in pure mats; P-2-3707, P-2-34-07. Also recorded in Gambaryan \& Cherdantseva (2002).

Chiloscyphus polyanthos (L.) Corda - L5, 6; 50-60; wet and submerged stones along watercourses in mixed and broadleaved forests; in pure mats; P-4-8-07, P-36-8-15, P-36-15-15. Also recorded in Gambaryan \& Cherdantseva (2002). 
Clevea nana (Shimizu \& S. Hatt.) Borovich. \& Bakalin (= Athalamia nana (Shim. et S. Hatt.) S. Hatt.) - L3; 286; mesic cliff crevice in part shade along stream; in pure mats; P-2-5-07.The latter specimen was cited in Borovichev \& Bakalin (2013)

Conocephalum japonicum (Thunb.) Grolle - Gambaryan \& Cherdantseva (2002).

*Conocephalum salebrosum Szweik., Buczk. \& Odrzyk. - L1, 3, 4; 130-320; humus and humic soil, moist boulders along and aside watercourses in mixed and broadleaved forests; in pure mats; P-2-28-07, P-2-27-07, P-1-27-07, P-4025-15, P-37-15-15. The species was also recorded in Borovichev et al. (2009).

*Cylindrocolea kiaeri (Austin) Váňa (=Cephaloziella kiaeri (Austin) S.W. Arnell) - L2; 500; mesic cliffs; in pure mats or together with Bazzania denuidata, Odontoschisma pseudogrossiverrucosum, Plicanthus birmensis; P-3-25-07, P-3-5a-07, P-3-5-07, P-3-1-07. The two former specimens were cited in Ellis et al. (2016).

*Diplophyllum taxifolium (Wahlenb.) Dumort. - L2, 4; 320-500; cliff crevices in mixed forests; in pure mats or together with Blepharostoma $\mathrm{cf}$. trichophyllum, Lepidozia reptans; P-3-28-07, P-3-6-07, P-40-18-15.

*Fuscocephaloziopsis catenulata (Huebener) Váňa et L. Söderstr. (=Cephalozia catenulata (Huebener) Lindb.) L2; 500; moist cliffs in mixed forest; in pure mats or together with Cephalozia otaruensis, Harpanthus flotovianus; P-335-07, P-3-38a-07.

Fuscocephaloziopsis lunulifolia (Dumort.) Váňa et L. Söderstr. - L2, 4; 320-500; moist decaving wood in part shade in mixed forests; in pure mats or with Calypogeia azurea; P-3-32-07, P-40-9-15. Also recorded in Gambaryan \& Cherdantseva (2002).

Frullania appendiculata Steph. - L2, 3, 4; 150-500; mesic cliffs in part shade, in mixed forests; in pure mats; P-245-07, P-2-48-07, P-3-8-07, P-37-11-15, P-40-15-15. Also recorded in Gambaryan \& Cherdantseva (2002).

Frullania muscicola Steph. - L1, 2, 3, 4; 130-500; trunks of Abies and Betula in mixed and broadleaved forests; in pure mats; P-3-39-07, P-2-23-07, P-1-14-07, P-1-12-07, P-37-22-15. Also recorded in Gambaryan \& Cherdantseva (2002).

*Frullania muscicola Steph. var. inueana (Steph.) Kamim. - L5; 60; mesic cliffs in part shade, in mixed forests; in pure mats; P-38-2-15.

Frullania taradakensis Steph. - L1, 3, 4; 130-286; mesic cliffs in part shade in mixed forests; in pure mats or together with Lejeunea japonica, Metzgeria lindbergii, Porella caespitans, P. grandiloba, P. vernicosa; P-2-44-07, P-2-43-07, P-2-42-07, P-2-26-07, P-2-25-07, P-1-23-07, P-1-16-07, P-1-15-07, P-1-13-07, P-1-10-07, P-1-9-07, P-37-24-15, P-37-9-15. Also recorded in Gambaryan \& Cherdantseva (2002).

* Geocalyx graveolens (Schrad.) Nees. - L3, 4; 330; moist decaying wood in part shade, in mixed forests; together with Liochlaena subulata, Lophocolea heterophylla; P-41-9-15, P-40-8-15.

*Harpanthus flotovianus (Nees) Nees. - L1; 140; moist to wet decaying wood in part shade; together with Fuscocephaloziopsis catenulata, Cephalozia otaruensis; P-39-6-15.

${ }^{*}$ Harpanthus scutatus (F. Weber et D. Mohr) Spruce. L4; 150; moist decaying wood in part shade; in pure mats; P-37-2-15.

*Jungermannia atrovirens Dumort. - L5; 60; wet boul- ders near stream, in part shade, in broadleaved forest; in pure mats; P-36-1-15, P-36-9-15.

*Jungermannia cf. pumila With. - L1; 140; moist boulder near stream in coniferous forest; in pure mats; P-39-1-15.

${ }^{*}$ Kurzia makinoana (Steph.) Grolle - L2; 500; mesic cliffs in part shade, in mixed forests; in pure mats; P-3-10-07.

*Lejeunea japonica Mitt. - L1, 2, 3, 5; 60-500; mesic cliffs, rarely decaying wood, in part shade, in mixed and broadleaved forests; together with Apometzgeria pubescens, Lophocolea itoana; P-2-22-07, P-1-19-07, P-3-14-07, P-36-215, P-38-3-15, P-40-2-15.

*Lepidozia reptans (L.) Dumort. - L2; 500; decaying wood in mixed forests; together with Bazzania denudata, Diplophyllum taxifolium, Tritomaria exsecta; P-3-28-07, P-3-36-07, P-3-37-07.

*Lepidozia subtransversa Steph. - L3; 330; moist boulder in part shade in mixed forest; in pure mats; P-41-4-15.

*Liochlaena subulata (A.Evans) Schljakov - L1, 2, 5; 60-500; moist decaying wood and boulders in part shade, in mixed forests; in pure mats or together with Aneura pinguis, Mylia verrucosa; P-1-2-07, P-1-6-07, P-1-7-07, P-3-29-07, P-3-34-07, P-36-6-15, P-39-2-15, P-39-7-15.

*Lophocolea heterophylla (Schrad.) Dumort. - L3, 4; 320-330; mesic to moist decaying wood in part shade in mixed and broadleaved forests; in pure mats or together with Riccardia palmata; P-40-5-15, P-41-11-15.

*Lophocolea itoana Inoue - L2; 500; decaying wood in mixed forest, in part shade; together with Metzgeria pubescens, Lejeunea japonica; P-3-14-07.

*Lophocolea minor Nees - L1, 3; 130-286; decaying wood, trunk bases and moist boulders in mixed and broadleaved forests; P-2-30-07, P-2-20-07, P-1-25-07.

Marchantia polymorpha L. - Gambaryan \& Cherdantseva (2002).

Metacalypogeia cordifolia (Steph.) Inoue - L2, 3, 4; 150-500; moist cliffs and decaying wood in part shade, in mixed forests; in pure mats or together with Plagiochila ovalifolia, Radula obtusifolia, Scapania parvitexta, Schistochilopsis cornuta; P-3-24-07, P-2-32-07, P-2-31-07, P-2-4-07, P-4019-15, P-37-13-15, P-41-1-15, P-2-15-07, P-37-14-15. Also recorded in Gambaryan \& Cherdantseva (2002).

*Metzgeria lindbergii Schiffn. - L2, 3; 286-500; cliffs and boulders in mixed forests; in pure mats or together with Porella caespitans, Frullania taradakensis; P-2-3-07, P-2-40-07, P-2-41-07, P-2-42-07, P-3-13-07, P-41-15-15, P-41-12-15. (Gambaryan \& Cherdantseva 2002, as Metageria conjugata Lindb.).

Metzgeria pubescens (Schrank) Raddi (= Apometzgeria pubescens (Schrank) Kuwah.) - L3, 5; 150-500; mesic cliffs in mixed forests; in pure mats or together with Lejeunea japonica; P-3-14-07, P-3-18-07, P-37-10-15. Also recorded in Gambaryan \& Cherdantseva (2002).

Mylia taylori (Hook.) Gray - The species was recorded by Gambaryan \& Cherdantseva (2002), but vouchers not found, the record may be based on misiderntification of $M$. verrucosa - the taxon sparsely distributed in the reserve, but not recorded in Gambaryan \& Cherdantseva (2002).

*Mylia verrucosa Lindb. - L2, 3; 500; decaying wood in part shade, in mixed forest; together with Liochlaena subulata, Metacalypogeia cordifolia, Schistochilopsis cornuta; P-3-29-07, P-331-07, P-41-1-15.

*Odontoschisma pseudogrosseverrucosum Gradst., 
S.C. Aranda \& Vanderp. - L2; 500; mesic cliffs in part shade in mixed forests; together with Bazzania ovifolia, Cylindrocolea kiaeri, Plicanthus birmensis; P-3-1-07, P-3-2-07, P-3-507, P-3-5a-07, P-3-11-07, P-3-25-07, P-3-26-07.

Pedinophyllum truncatum (Steph.) Inoue. - L1; 130 140; decaying wood in broadleaved and coniferous forests; in pure mats; P-1-4-07, P-1-5-07, P-39-5-15. Also recorded in Gambaryan \& Cherdantseva (2002).

Pellia neesiana (Gottsche) Limpr. - Gambaryan \& Cherdantseva (2002).

Phaeoceros laevis (L.) Prosk. - Gambaryan \& Cherdantseva (2002).

Plagiochila hakkodensis Steph. - Gambaryan \& Cherdantseva (2002).

* Plagiochila ovalifolia Mitt. - L4, 5; 60-320; mesic to moist boulders (also near streams) in part shade, in mixed and broadleaved forests; together with Metacalypogeia cordifolia, Radula obtusifolia, Scapania parvitexta; P-40-13-15, P-3611-15, P-37-14-15, P-37-16-15.

* Plectocolea infusca Mitt. var. infusca - L4, 5; 286-320; moist cliff in part shade in mixed forest; in pure mats; P-4020-15.

*Plectocolea infusca Mitt. var. recondita Bakalin - L4; 150 ; mesic cliffs in part shade in mixed forest; in pure mats; P-37-8-15, P-37-18-15.

Plectocolea ovalifolia (Amak.) Bakalin et Vilnet - (Gambaryan \& Cherdantseva 2002, as P. infusca Mitt. var. ovalifolia Amak.)

Plicanthus birmensis (Steph.) R.M. Schust. - L2; 500; mesic cliffs in rather open conditions, in mixed forest; in pure mast or together with Cephaloziella kiaeri, Odontoschisma psendogrossiverrucosum; P-3-4-07, P-3-5-07, P-3-5a-07, P-3-907 (as Chandonanthus birmensis Steph. in Gambaryan \& Cherdantseva 2002).

*Porella caespitans (Steph.) S. Hatt. - L3, 4; 150-286; large boulders at the ridge with lighted mixed forests; together with Frullania taradakensis, Metzgeria lindbergii; P-2-4207, P-37-12-15.

* Porella faurieri (Steph.) S. Hatt. - L2, 3, 5; 60-500; tree base and mesic to moist boulders in mixed and broadleaved forests; in pure mats; P-3-42-07, P-36-12-15, P-41-14-15.

Porella gracillima Mitt. - Gambaryan \& Cherdantseva (2002).

Porella grandiloba Lindb. - L2, 3, 4, 5; 60-500; shaded vertical cliffs, mesic boulders and tree trunks in part shade in mixed and broadleaved forests; in pure mats or together with Frullania taradakensis; P-2-1-07, P-2-2-07, P-2-24-07, P-3-12-07, P-36-7-15, P-36-10-15, P-37-23-15, P-40-14-15. Also recorded in Gambaryan \& Cherdantseva (2002).

Porella spinulosa (Steph.) S. Hatt. - The species was recorded by Potemkin (2008), but not found in our collections. We suggest the report may be based on poorly developed plants of P. vernicosa.

*Porella ulophylla (Steph.) S. Hatt. - L1, 2, 4, 8; 50-500; trunk base, bark of trees and cliffs in part shade to rather open conditions, in mixed forests; in pure mats; P-1-11-07, P-3-45-07, P-4-5-07, P-4-6-07, P-37-26-15.

Porella vernicosa Lindb. - L1, 3, 4; 130-500; mesic boulders and tree trunks in part shade, in mixed and broadleaved forests; together with Frullania taradakensis, Radula constricta P-1-8-07, P-2-43-07, P-3-19-07 P-37-25-15. Also recorded in Gambaryan \& Cherdantseva (2002).
Radula complanata (L.) Dumort. - Gambaryan \& Cherdantseva (2002).

* Radula constricta Steph. - L4; 500; cliffs and tree bases in mixed forest; in pure mats or together with Porella vernicosa; P-3-19-07, P-3-44-07.

* Radula obtusiloba Steph. - L3, 4; 150-330; mesic to moist cliffs in part shade, in mixed forests; together with Metacalypogeia cordifolia, Plagiochila ovalifolia, Scapania parvitexta; P-40-22-15, P-41-3-15, P-37-14-15.

Reboulia hemisphaerica (L.) Raddi ssp. orientalis R.M. Schust. - L4; 150; mesic cliff crevice in part shade, in mixed forest; in pure mats; P-2-6-07, P-37-17-15. Also recorded in Gambaryan \& Cherdantseva (2002), without indication of subspecies name.

*Riccardia palmata (Hedw.) Carruth. - L4, 5; 60-330; moist decaying wood in part shade, in broadleaved and mixed forests; together with Cephalozia otaruensis, Lophocolea heterophylla; P-36-3-15, P-37-1-15.

Riccia beyrichiana Hampe - L6; 50; shaded cliff crevices in broadleaved forest; in pure mats; P-4-4-07. Together with Riccia bifurca. The species is recorded by Borovichev \& Bakalin (2016a) from the same locality.

Riccia bifurca Hoffm. - L6; 50; shaded cliff crevices in broadleaved forest; in pure mats; P-4-4-07. Together with Riccia beyrichiana. The species is recorded by Borovichev \& Bakalin (2016a) from the same locality.

*Scapania ciliata Sande Lac. - L2, 3; 330-500; mesic cliffs and boulders in mixed forests; together with Barzania denudata, B. parabidentula, Metacalypogeia cordifolia; P-3-3-07, P-3-7-07, P-3-27-07, P-41-17-15.

*Scapania parvitexta Steph. - L3, 4; 150-330; moist boulders and cliffs in part shade, in mixed forests; together with Cephalozia otaruensis, Metacalypogeia cordifolia, Plagiochila ovalifolia, Radula obtusifolia, Tritomaria exsecta; P-37-14-15, P-41-7-15, P-41-13-15, P-41-6-15.

*Schistochilopsis cornuta (Steph.) Konstant. - L3; 330; mesic decaying wood in part shade, in mixed forest; in pure mats or together with Metacalypogeia cordifolia, Mylia verrucosa; P-41-2-15.

*Syzygiella autumnalis (DC.) K. Feldberg, Váňa, Hentschel \& Heinrichs - L1, 2, 3, 4; 286-500; cliffs, decaying wood and trunk bases, in part shade, in mixed forests; in pure mats or together with Bazzania denudata; P-3-21-07, P-2-39-07, P-2-19-07, P-2-18-07, P-40-1-15.

Targionia hypophylla L. - L1, 5; 60, 129; moist cliff crevice in part shade, in mixed forests; in pure mats; P-1-1707, P-38-4-15, P-38-6-15. Also recorded in Gambaryan \& Cherdantseva (2002).

Trichocoleopsis sacculata (Mitt.) S. Okamura - L2; 500; tree base in part shade, in mixed forest; in pure mats; P-340-07, P-3-41-07. Also recorded in Gambaryan \& Cherdantseva (2002).

*Tritomaria exsecta (Schmidel) Schiffn. ex Loeske - L. 3; 330; moist boulder in part shade, in mixed forest; together with Cephaloria otaruensis, Scapania parvitexta; P-41-6-15.

*Xenochila integrifolia (Mitt.) Inoue. - L. 2, 3, 4; 60-320; moist boulders and cliffs in part shade; in pure mats; P-238-07, P-36-13-15, P-40-23-15. 


\section{ACKNOWLEDGEMENTS}

Authors are sincerely grateful to the directorial board of Kedrovaya Pad' Reserve for providing of free visitor room in the course of our field study in 2015 and to Mr. Andreas K. Donadel for his help in map preparation. The work was partially supported by the Russian Foundation for Basic Researches (grant no. 15-34-20101).

\section{LITERATURE CITED}

Aranda, S.C., S.R. Gradstein, J. Patiño, B. Laenen, A. Désamoré \& A. Vanderpoorten 2014. Phylogeny, classification and species delimitation in the liverwort genus Odontoschisma (Cephaloziaceae). Taxon 63(5):1008-1025.

Azbukina, Z.M., A.B. Bogacheva, E.M. Bulah, L.N. Vasiljeva, S.K. Gambaryan, O.K. Govorova, L.N. Egorova, L.A. Knyazheva, R.I. Korkishko, L.A. Medvedeva, M.M. Nazarova, I.F. Skirina, S.I. Chabanenko, V.Ya. Cherdantseva 2002. Introduction. In: Cadaster of plants and fungi of Kedrovaya Pad' Reserve: check-lists, pp. 3-5, Dal'nauka, Vladivostok (in Russian). [Азбукина 3.М., Богачева А.В., Булах E.M., Васимьева А.Н., Гамбарян С.К., Говорова О.К., Егорова А.Н., Княжева А.А., Коркишко Р.И., Медведева М.А., Назарова М.М., Скирина И.Ф., Чабаненко С.И., Черданцева В.Я. 2002. Введение // Кадастр растений и грибов заповедника «КеАровая падь»: Списки видов. ВАадивосток: Аальнаука. С. 3-5.]

Bakalin, V.A. 2008. On taxonomy of some Hepatics from Primorsky Territory (Russian Far East), with the list of taxa of the territory. Arctoa 17:101-108.

Bakalin, V.A., A.V. Vilnet, T. Furuki, T. Katagiri 2014. Taxonomic novelties in Solenostoma-Plectocolea complex (Solenostomataceae, Hepaticae) in East Asia. Botanica Pacifica 3(2): 3-18.

Bakalin, V.A. 2016. A revision of Lepidoziaceae (Hepaticae) in the Russian Far East I. Bazzania. Botanica Pacifica 5(1): 33-52.

Borovichev, E.A., N. Kalinauskaite \& N.A. Konstantinova 2009. On the distribution of Conocephalum conicum and C. salebrosum (Marchantiophyta) in Russia. Arctoa 18: 115-120.

Borovichev, E.A. \& V.A. Bakalin 2013 The Survey of Marchantiales from the Russian Far East I. The Review of Cleveaceae (Hepaticae). Botanica Pacifica 2013. 2(1): 53-61.

Borovichev, E.A., V.A Bakalin \& A.A Vilnet 2015. Revision of the Russian Marchantiales. II. A review of the genus Asterella P. Beauv. (Aytoniaceae, Hepaticae). Arctoa 24(2): 294-313.

Borovichev, E.A. \& V.A. Bakalin 2016a. Survey of the Russian Far East Marchantiales IV: A revision of Ricciaceae (Hepaticae). Botanica Pacifica 5(2): 3-29.

Borovichev, E.A. \& V.A. Bakalin 2016b. On Mannia triandra (Aytoniaceae, Marchantiophyta) in Eastern Asia. Herzogia 29(1):59-65.

Choi, S.S. \& V.A. Bakalin 2012. Lepidozia subtransversa Steph. - a new species for the Russian liverwort flora. Arctoa 21:189-192.

Ellis, L.T., M. Aleffi, A. Alegro, V. Segota, A.K. Asthana, R. Gupta, V.J. Singh, V.A. Bakalin, H. Bednarek-Ochyra, B. Cykowska-Marzencka, A. Benitez, E.A. Borovichev, A.A. Vilnet, N.A. Konstantinova, W.R. Buck, C. Caccia- toro, C. Sergio, J. Csiky, J. Deme, D. Kovacs, K. Damsholt, J. Enroth, P. Erzberger, V.E. Fedosov, E. Fuertes, S.R. Gradstein, N.J.M. Gremmen, T. Hallingback, I. Jukoniene, T. Kiebacher, J. Larrain, M. Lebouvier, M. Luth, Yu.S. Mamontov, A.D. Potemkin, Cs. Nemeth, J.A.W. Nieuwkoop, M. Nobis, M. Wegrzyn, P. Wietrzyk, F. Osorio, I. Parnikoza, V.M. Virchenko, D.F. Peralta, D.M. Carmo, V. Plasek, Z. Skoupa, S. Poponessi, R. Venanzoni, F. Puche, D. Purger, C. Reeb, R. Rios, E. Rodriguez-Quiel, C. Arrocha, M.S. Sabovljevic, N. Nikolic, A.D. Sabovljevic, E.L. dos Santos, J.G. Segarra-Moragues, S. Stefanut \& D. Stoncius 2016. New national and regional bryophyte records, 48. Journal of Bryology 38(3): 235-259.

Gambaryan, S.K. \& V.Ya. Cherdantseva 2002. Bryophytes. In: Cadaster of plants and fungi of Kedrovaya Pad' Reserve: check-lists, pp. 21-30, Dal'nauka, Vladivostok (in Russian). [Гамб́арян С.К., Черданцева В.Я. 2002. Мохообразные // КаАастр растений и грибов заповедника «КеАровая падь»: Списки видов. ВАаАивосток: Аальнаука. С. 21-30].

Kong, W-S, S. Lee, K. Yoon \& H. Park 2011. Environmental characteristics of wind-hole and phytogeographical values. Environmental Impact Assessment 20(3):381-395 (in Korean).

Kong, W-S, K. Yoon, I. Kim, Y. Lee \& S. Oh 2012. Spatial distributional characteristics of wind-hole and governance strategy. Environmental Impact Assessment 21(3):431443 (in Korean).

Nakamura, Y., P.V. Krestov 2005. Coniferous forests of the temperate zone of Asia. In: Coniferous forests. Ecosystems of the World, Vol. 6, (G.W. Goodall, ed.), pp. 163-220, Elsevier, Amsterdam, Boston, London et al.

Potemkin, A.D. 2008. New liverwort records from Primorsky Territory. 3. Arctoa 17:226.

Rakova, M.V. 1992. Biology of rare plant species of Kedrovaya Pad' Reserve. Dalnauka, Vladivostok, 175 pp. (in Russian). [Ракова М.В. 1992. Биология редких видов растений заповедника «КеАровая падь». ВАадивосток: Аальнаука, 175 с.].

Söderström, L., A. Hagborg, M. von Konrat, S. Bartholomew-Began, D. Bell, L. Briscoe, E. Brown, D.C. Cargill, D.P. Costa, B.J. Crandall-Stotler, E.D. Cooper, G. Dauphin, J.J. Engel, K. Feldberg, D. Glenny, S.R. Gradstein, X. He, J. Heinrichs, J. Hentschel, A.L. Ilkiu-Borges, T. Katagiri, N.A. Konstantinova, J. Larran, D.G. Long, M. Nebel, T. Pôcs, F. Felisa Puche, E. Reiner-Drehwald, M.A.M. Renner, A. Sass-Gyarmati, A. Schâfer-Verwimp, J.G.S. Moragues, R.E. Stotler, P. Sukkharak, B.M. Thiers, J. Uribe, J. Vâna, J.C. Villarreal, M. Wigginton, L. Zhang, R.-L. Zhu 2016. World checklist of hornworts and liverworts. PhytoKeys 59: 1-828.

Vasiliev, N.G., A.G. Pankratiev, E.G. Panov 1965. Kedrovaya Pad'Reserve (popular science overview). Dal'nevostochnoe knizhnoe izdatel'stvo, Vladivostok, 58 pp. (in Russian). [Васильев Н.Г., Панкратьев А.Г., Панов Е.Н. 1965. Заповедник «Кедровая падь» (научно-популярный очерк). ВАадивосток: Аальневосточное книжное из-

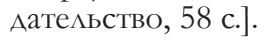

Vasiliev, N.G., S.S. Kharkevich, Yu.B. Shibnev. 1984. Kedrovaya Pad' Reserve. Lesnaya promyshlennost', Moscow, 197 pp. (in Russian). [Васильев Н.Г., Харкевич С.С., Шибнев Ю.Б. 1984. Заповедник «КеАровая падь». М.: Аесная промышленность, 197 с.]. 